\title{
KONSELING ISLAMI DAN PROBLEM SOLVING
}

\author{
Drs. Ali Musa Lubis, M.Ag \\ IAIN STS JAMBI
}

\begin{abstract}
Human always face many kinds of problem in their life. Some problems can solve easily, the others are difficult to solve and its causes mental disorders. As a khalifatullah in alardl, human has given potency to face the problems in their life. In Islamic counseling study, problem solving is the part of study that may help to answer the problem faced by human. The main study of this paper is related to strategies steps of problem solving in Islamic counseling perspective.
\end{abstract}

Key Words: Counseling, Islamic, Problem Solving

\begin{abstract}
Abstrak
Manusia selalu dihadapkan dengan berbagai masalah dalam hidupnya. Permasalahan itu ada yang bias diatasi dengan mudah, tetapi tidak sedikit pula yang tidak bisa diatasi sehingga menimbulkan gangguan mental, bahkan menjadi bias menjadi penyakit mental. Sebagai khalifatullah di al-ardl, manusia telah diberi potensi untuk menghadapi berbagai persoalan hidupnya. Di dalam kajian konseling Islami, problem solving merupakan bagian yang kajian yang dapat membantu menjawab persoalan yang dihadapi manusia. Di antara kajian pokok tulisan ini adalah berhubungan dengan langkah-langkah strategis penyelesaian masalah (problem solving) dalam persfektif konseling islami.
\end{abstract}

Kata Kunci : Konseling, Islami, Problem solving

\section{Pendahuluan}

Manusia adalah makhluk terbaik bila dibandingkan dengan makhlukmakhluk Allah yang lain. Berbagai potensi yang dimiliki oleh manusia menjadi faktor utama menjadikannnya lebih unggul dari pada makhluk yang lain. Kelebihan dan keunggulan ini menjadikannya pantas diberi amanah untuk menjadi khalifatullah fi al-ard.

Dalam menjalankan fungsinya sebagai khalifatullah terkadang manusia dihadapkan pada berbagai masalah. Ada orang yang mampu menyelesaikan masalahnya dengan baik sehingga masalah tersebut tidak menjadi batu sandungan baginya dalam meraih kesuksesan, tetapi tidak sedikit juga orang yang lemah dan tidak kuat menyelesaikan problem hidupnya sehingga berakibat pada gangguan mental ${ }^{1}$ yang dapat mengganggu aktifitas kekahlifahannya. Dalam kondisi seperti ini manusia memerlukan konseling untuk dapat keluar dari berbagai persoalan yang pada gilirannya ia tidak larut dalam permasalahan.

${ }^{1}$ Menurut Zakiah Daradjat, gangguan jiwa adalah kumpulan dari keadaan-keadaan yang tidak normal, baik yang berhubungan dengan fisik maupun dengan mental. Keabnormalan tersebut bukan disebabkan sakit atau rusaknya bagian-bagian anggota badan, meskipun terkadang gejalanya terlihat pada fisik. Ada beberapa jenis gangguan jiwa, yaitu : neurasthenia, hysteria, psychasthenia, Fatishim, gagap berbicara, ngompol, Keabnormalan seksuil. Zakiah Daradjat, Kesehatan Mental, (Jakarta : CV Masagung, 1989), hal. 17-62 
Penyelesaian masalah (problem solving) merupakan bagian yang tidak terpisahkan dari konseling. Menurut hemat penulis, inti klimak dari kegiatan konseling terletak pada kemampuan menyelesaikan masalah. Berhasil tidaknya pelayanan konseling tergantung pada keberhasilan problem solving itu sendiri.

Islam adalah agama rahmatan lil'alamin. Ia hadir untuk membimbing manusia ke arah kehidupan yang lebih bermakna. Di dalamnya terdapat ajaran yang memberikan solusi terhadap berbagai permasalahan hidup yang dihadapi manusia. Tulisan ini akan memaparkan konseling islami sebagai upaya penyelesaian masalah manusia.

\section{Pandangan Islam tentang Masalah pada Manusia}

Di dalam Kamus Besar Bahasa Indonesia, masalah berarti sesuatu yang harus diselesaikan (dipecahkan) ${ }^{2}$. Dalam bahasa Inggris, masalah diistilahkan dengan problem. As. Hornby mendefenisikan problem sebagai question to be solved or decided ${ }^{3}$, permasalahan yang harus diseselesaikan. Masalah dapat juga dapat diartikan sebagai suatu deviasi antara dassain dan dassolen, antara yang seharusnya (should) terjadi dengan kenyataan (actual). ${ }^{4}$ Dengan demikian, dalam persfektif Konseling dan Kesehatan Mental, Ketidak mampuan menyesuaikan dengan diri sendiri, dengan orang lain serta lingkungan merupakan permasalahan hidup bagi manusia. Permasalahan ini akan menimbulkan gangguan kesehatan mental, berupa gangguan jiwa dan penyakit jiwa. Gejala gangguan jiwa pada manusia itu berupa rasa cemas yang tidak jelas sebabnya, seperti malas, tidak bergairah, lesu. Gejala seperti itu bisa meningkat pada penyakit kejiwaan, seperti anxiety, neurasthebia, hysteria, dan sebagainya. ${ }^{5}$

Menurut Saiful Akhyar, manusia ${ }^{6}$ dengan berbagai kebutuhannya ${ }^{7}$ merupakan titik tolak lahirnya suatu problem. ${ }^{8}$ Ketidakmampuan manusia

\footnotetext{
2Departemen Pendidikan dan Kebudayaan, Kamus Besar Bahasa Indonesia, (Jakarta : 1995), hal. 633.

${ }^{3}$ A.S hornby, et al., Oxford Advanced Learner's Dictionary of Current English, (London : Oxford University Press, 1992 ), hal. 664

4 Syukur Kholil (Ed.), Bimbingan Konseling Dalam Persfektif Islam, (Bandung : Cita Pustaka, 2009), hal. 22

${ }^{5}$ Zakiah Daradjat, Kesehatan Mental.,opcit., hal. 11-12

${ }^{6}$ Menurut Prayitno, ada beberapa dimensi kemanuisaan; dimensi keindividualan (individualitas), dimensi kesosialan (sosialitas), dimensi kesusilaan (moralitas), dan dimensi keberagaman (religiusitas) Prayitno dan Erman Amti, Dasar-Dasar Bimbingan dan Konseling, (Jakarta: Rineka Cipta, 2008), hal. 16

7Ramayulis membagi kebutuhan manusia kepada kebutuhan individu, kebutuhan sosial, kebutuhan akan gama dan kebutuhan akan agama Islam. (Ramayulis, Psikologi Agama, (Jakarta : Kalam mulia, 2009), hal. 38-51) Menurut Zakiah Daradjat, seperti dikutip oleh Ramayulis, kebutuhan manusia dapat dibagi kepada dua kebutuhan pokok, yaitu kebutuhan primer dan skunder. Kebutuhan primer merupakan kebutuhan jasmaniah seperti makan, minum, sek dan sebagainya. Menurut para ahli kebutuhan sek merupakan kebutuhan yang banyak mempengaruhi mental manusia, terutama di kalangan remaja. Kebutuhan seksuil yang tidak teratasi di kalangan remaja akan menimbulkan keabnormalan seksuil, seperti homoseksualitas, pedophilia, bestiality, zoophilia, necrophilia, pornography, dll. Sementara itu, kebutuhan sekunder merupakan kebutuhan rohaniah yang dirasakan sejak kecil. Selanjutnya Zakiah Daradjat membagi kebutuhan
} RI'AYAH, Vol. 01, No. 02 Juli-Desember 2016 
memenuhi berbagai kebutuhannya merupakan faktor utama munculnya masalah pada manusia.

Sebagai makhluk individu, makhluk sosial, makhluk Allah/makhluk religius yang menjalin hubungan dengan Allah/makhluk religius dan menjalin hubungan dengan sesama manusia menyebabkan munculnya masalah-masalah dalam kehidupannya akan meliputi problema fisik, psikis, keluarga, penyesuaian diri dengan lingkungan/masyarakatnya, dan problema religius. Selain itu, problema lain yang timbul dari internal manusia ataupun desakan eksternal ${ }^{9}$.

Problema-problema tersebut pada gilirannya memperlihatkan fenomenafenomena berupa aneka akibat, seperti frustrasi, putus asa, stress, konflik kejiwaan, merasa berdosa, merasa tidak bahagia dan kesenjangan-kesenjangan psikis lainnya. ${ }^{10}$

Manusia selalu dihadapkan kepada berbagai masalah, bahkan sering dikatakan " tiada hidup tanpa masalah". Artinya, permasalahan tidak pernah luput dari manusia selagi manusia hidup di dunia ini, baik masalah sederhana yang mampu diselesaikan secara mkandiri, tanpa memerlukan bantuan orang lain, maupun masalah itu rumit dan sulit yang memerlukan bantuan dan nasihat orang lain.

Indikasi manusia sebagai makhluk berproblema kelihatan dengan jelas pada temu dialogis yang rekonstruksi Alquran dalam surah al-Baqarah (2) ayat 30, dimana digambarkan suasana terjadinya dialog antara Allah dan malaikat ketika Allah akan menjadikan Adam sebagai khalifah di muka bumi. Kenyataan menunjukkan bahwa prediksi-prediksi, yang disampaikan malaikat dalam ayat tersebut, bahwa manusia adalah makhluk berpotensi "perusak" serta " penumpah darah" bukan hanya perkiraan teoritis tetapi mencerminkan kebenaran serta keotentikan dan kemukjizatan wahyu ilahi11.

Di dalam Islam, masalah yang dihadapi manusia merupakan ujian dan cobaan dari bagi orang-orang beriman yang hikmahnya untuk menguji keimanan dan kesabarannya. Banyak suri tauladan Rasulullah yang perlu dicontoh. Beliau pernah dilempar kotoran oleh orang-orang kafir Mekkah, kedua

manusia kepada enam macam kebutuhan, yaitu kebutuhanakan rasa kasih saying, kebutuhan rasa aman, kebutuhan rasa harga diri, kebutuhan akan rasa bebas, kebutuhan akan rasa sukses, kebutuhan akan rasa ingin tahu.Ibid., hlm. 38-44. George J. Mouly, seperti dikutif Saiful Akhyar mengklassifikasikan kebutuhan manusia menjadi dua bagian, yakni : psiological needs (kebutuhankebutuhan fisik), yang terdiri dari kebutuhan akan makanan, minuman, tidur, dan istirahat, beraktifitas, dan kebutuhan akan seks. Pskologikal needs (kebutuhan psikis), yang terdiri dari kebutuhan akan rasa kasih saying, rasa memiliki, prestasi, rasa kebebasan, pengakuan social dan kebutuhan akan harga diri. Abdul Aziz al-Quussiy juga menyebut rasa aman, rasa kasih saying, kebebasan, rasa sukses, pembimbing dan pengendali. Saiful Akhyar, Konseling Islami dan Kesehatan Mental, op.cit., hal. 165.

8Saiful Akhyar, Konseling Islami ,op.cit., hal. 105

${ }^{9}$ Ibid

${ }^{10} \mathrm{Ibid}$

11 Saiful Akhyar, Konseling Islami dan Kesehatan mental, (Bandung: Citapustaka, 2011),

RI'AYAH, Vol. 01, No. 02 Juli-Desember 2016 
kakinya dicederai dan wajahnya mereka lukai. Dikepung kaumnya untuk beberapa lama hingga beliau hanya dapat makan dedaunan, diusir dari Mekkah. Seorang putera serta beberapa puterinya meninggal dunia pada saat beliau sedang senang-senangnya membelai mereka. Sebelum itu, Nabi Zakaria dibunuh kaumnya, Nabi Yahya dijagal, Nabi Musa diusir dan dikejar-kejar, dan Ibrahim dibakar. Cobaan-cobaan itu, juga menimpa para khalifah. Umar .r.a dilumuri dengan darahnya sendiri, Utsman dibunuh diam-diam, dan Ali ditikam dari belakang. ${ }^{12}$

Di dalam Alquran, surah al-Baqarah ayat 155-157 dijelaskan, yang terjemahnya sbb :

"Dan sungguh akan Kami berikan cobaan kepadamu, dengan sedikit ketakutan, kelaparan, kekurangan harta, jiwa dan buah-buahan. Dan berikanlah berita gembira kepada orang-orang yang sabar, (yaitu) orang-orang yang apabila ditimpa musibah, mereka mengucapkan, "Innaa lillaahi wa innaa ilaihi raaji uun" Mereka itulah yang mendapat keberkatan yang sempurna dan rahmat dari Tuhan mereka, dan mereka itulah orang-orang yang mendapat petunjuk." 13

Pada ayat lain di disebutkan: "Apakah kamu mengira bahwa kamu akan masuk surga, padahal belum datang kepadamu (cobaan) sebagaimana halnya orang-orang yang terdahulu sebelum kamu? Mereka ditimpa oleh malapetaka dan kesengsaraan serta digoncangkan (dengan bermacam-macam cobaan)" 14.

Inti ayat di atas adalah Allah menggambarkan bahwa cobaan yang diberikan kepada manusia adakalanya bersifat psikis (ketakutan, kegelisahan jiwa) dan ada kalanya bersifat material (kelaparan, kekurangan harta/benda). Demikian juga makna surah at-Tagabun ayat 15 adalah menegaskan bahwa harta dan anak-anak-anak merupakan ujian yang nyata bagi manusia, baik keberadaannya maupun ketiadaannya ${ }^{15}$.

\section{Potensi Dasar Manusia dalam Menyelesaikan Masalah}

Potensi dasar artinya potensi yang dibawa sejak lahir. Potensi dasar itu dalam bahasa agama diistilahkan dengan fithrah. Di dalam surah ar-Rum, ayat 30 Allah menjelaskan bahwa manusia dijadikan menurut fitrah-Nya.

"Maka hadapkanlah wajahmu dengan lurus kepada agama (Allah); (tetaplah atas) fithrah Allah yang telah menciptakan manusia menurut fitrah itu. Tidak ada perubahan pada fitrah Allah (itulah agama yang lurus); tetapi kebanyakan manusia tidak mengetahui ${ }^{16}$.

Fithrah Allah dalam ayat ini berarti ciptaan Allah, yakni Allah menciptakan manusia dengan dibekali naluri beragama, mentauhidkan Tuhan.

12 'Aid al-Qarni, La Tahzan, (Jakarta : Qisthi, 2003), hal. 33

${ }^{13}$ Departemen Agama RI, Alquran dan Terjemahnya, (Madinah Munawwaroh, Mujamma' Khadim al Haramain asy-Syarifain, $1412 \mathrm{H}), \quad$ hal. 39

14 Ibid., hal. 51

15 Saiful Akhyar Lubis, Konseling Islam dan Kesehatan Mental, op.cit., hal. 117

16 Departemen Agama RI, Alquran dan Terjemahnya., op.cit., hal. 645

RI' AYAH, Vol. 01, No. 02 Juli-Desember 2016 
Hal ini seperti dikemukakan oleh al-Gazali. Menurutnya, semua anak cucu Adam dilahirkan difitrahkan beriman dan mengetahui Allah sesuai dengan fitrahnya. ${ }^{17}$ Muhaimin dan Abd Mujib juga memaknai fitrah dengan jiwa tauhid. Setiap anak yang lahir telah membawa jiwa tauhid, paling tidak telah mempunyai kecenderungan mengesakan Allah ${ }^{18}$.Murtani juga memaknai fitrah sebagai sikap bertauhid kepada Allah SWT, sejak manusia dalam kandungan mereka telah melakukan perjanjian dengan Allah untuk beriman dan bertauhid kepada-Nya. ${ }^{19}$ Kecenderungan manusia memiliki rasa beragama juga diakui para ahli psikologi modern. Henry Bergson, seperti dikutip Abuddin Nata, mengatakan: Mungkin saja sekelompok manusia tidak memiliki sains, seni atau filsafat, tetapi tidak munkin ada kelompok manusia yang tidak memiliki agama. Erich Fromn menyatakan bahwa pengabdian kepada kekuatan yang transcendent adalah suatu ekspresi kebutuhan dan kesempurnaan. Oleh karena itu, tidak ada seorang pun yang tidak memiliki agama. ${ }^{20}$

Menurut Hasan langgulung, potensi manusia menurut pandangan Islam, tersimpul pada al-asma' al-husna, yaitu sifat-sifat Allah yang berjumlah 99. Pengembangan sifat-sifat ini pada diri manusia itulah ibadat dalam arti kata yang luas, sebab tujuan manusia diciptakan Allah adalah menyembah Allah. Sebagai contoh, sifat al-Quddus. Untuk mengembangkan kesucian, kita diperintahkan mengerjakan ibadah formal yang terdiri dari rukun Islam. Syahadat berfungsi mensucikan manusia dari niat dan fikiran manusia dari segala kesyirikan. Sembahyang didahului oleh kesucian badan, seperti suci dari hadats kecil. Hati juga harus suci dari riya' atau sifat pura-pura, supaya jangan termasuk golongan munafik. Zakat adalah usaha mensucikan harta dari saegala yang tidak halal. ${ }^{21}$

Permasalahan hidup yang berakibat pada berbagai gangguan jiwa akan dapat teratasi dengan menumbuhkan dan mengembangkan fitrah atau potensi dasar bawaan manusia. Hal ini seperti dikemukakan Zakiah Daradjat berikut ini:

"Ketenangan batin dan kebahagiaan sejati hanya dapat ditemukan di sumber aslinya, yakni Allah. Justru itu setiap permasalahan yang dihadapi manusia dalam kehidupannya harus dikembalikan kepada Allah. Dari Allahlah petunjuk dan kekuatan untuk menyelesaikannya dapat diperoleh. Zakiah Daradjat menyebut kebahagiaan yang hakiki akan dapat diperoleh dengan iman. ${ }^{22}$

${ }_{17}$ Abu Hamid Muhammad bin Muhammad al-Gazali, Ihya' Ulum ad-Din, Juz, I, (Kairo: mMaktabah wa Maktabah al-Masyhad al-Husain, tt), hal. 86

18 Muhaimin dan Abd.Mujib, Pemikiran Pendidikan Islam, (Bandung : Trigenda Karya, 1993), hal.14

${ }^{19}$ Abuddin Nata, Kapita Selekta Pendidikan Islam, (Bandung: Angkasa, 2003), hal. 215

${ }^{20}$ Abuddin Nata, Pendidikan dalam Persfektif Alquran, (Jakarta : UIN Jakarta Press, 2005), hal.168

${ }^{21}$ Hasan Langgulung, Manusia dan Pendidikan, (Jakarta: Pustaka al-husna baru, 2004), hal.224

22 Zakiah Daradjat, Kebahagiaan, (Jakarta : YPI Ruhama' , 1998), hal.13

RI'AYAH, Vol. 01, No. 02 Juli-Desember 2016 
Kartini Kartono dan JennyAndari, seperti dikutif oleh Saiful Akhyar, menegaskan,bahwa keyakinan pada kebesaran Ilahi pasti menonjolkan kesejahteraan jiwa, juga memberikan rasa aman, rasa adil, kepercayaan dan harapan, baik untuk saat sekarang di dunia, maupun di akhirat nantinya. Kepercayaan kepada Allah juga menyadarkan manusia tentang hakikat relasinya dengan manusia lain, sehingga ia mencintai sesamanya, memandang setiap orang sebagai saudaranya sendiri, bersedia memberi maaf dengan tulus, dan melihat pribadi lain sebagai buah ciptaan Allah. ${ }^{23}$

Dari beberapa pendapat di atas, jelaslah potensi keimanan dan keyakinan akan sifat-sifat utama yang dimiliki akan dapat mengatasi berbagai permasalahan hidup. Keyakinan akan adanya Yang Maha Pemurah, Maha Penyayang dan Maha dalam segala-galanya akan menimbulkan rasa aman pada diri orang yang mengimaninya. Dengan demikian, maka permasalahan hidup pun akan teratasi.

\section{Keberanian Mengambil Keputusan}

Pengambilan keputusan identik dengan penyelesaian masalah (problem solving). Menurut Sudarsono, seperti dikutip Lahmuddin Lubis dalam buku Bimbingan Konseling Dalam Persfektif Islam, Problem solving adalah Proses penyelesaian masalah atau kejadian, upaya pemilihan salah satu dari beberapa alternatif atau option yang mendekatkan kebenaran dari tujuan tertentu. ${ }^{24}$ H.B. Siswanto mendefenisikan pengambilan keputusan adalah serangkaian aktivitas yang dilakukan oleh seseorang dalam usaha memecahkan permasalahan yang sedang dihadapi kemudian menetapkan berbagai alternatif yang dianggap paling rasional dan sesuai dengan lingkungannya. ${ }^{25}$ Pengambilan keputusan adalah pemilihan terhadap berbagai alternatif tindakan yang mungkin dipilih yang prosesnya melalui mekanisme tertentu. ${ }^{26}$

Beberapa definisi tersebut mengindikasikan dalam pengambilan keputusan seseorang dihadapkan pada beberapa pilihan. Pilihan-piihan itu terkadang memiliki keunggulan tersendiri. Oleh karena itu, dalam pengambilan keputusan, apalagi keputusan itu mengandung resiko, sesorang yang akan mengambil keputusan terkadang diliputi keraguan dan rasa takut.

Mengambil keputusan tidaklah mudah, Pengambilan keputusan memerlukan keberanian yang penuh perhitungan. Tanpa keberanian, Seringkali terjadi kesalahan dalam pengambilan sebuah keputusan. Akibatnya kesempatan meraih kesuksesan menjadi hilang.

23 Saiful akhhyar, Konseling Islami dan Kesehatan Mental, op.cit., hal.76

${ }^{24}$ Syukur Khalil, Bimbingan Konseling dalam Persfektif Islam, op.cit., hal 26

${ }^{25}$ H.B. Siswanto, Pengantar Manajemen, (Jakarta : Bumi Aksara, 2010), hal. 171

${ }^{26}$ Abdullah Aziz Wahab, Anatomi Organisasi, (Bandung: Kerjasama Sekolah Pascasarjana Universitas Pendidikan Indonesia, 2006), hal. 163

RI'AYAH, Vol. 01, No. 02 Juli-Desember 2016 
Di dalam Islam, sifat berani27 (asy-Syaja'ah) termasuk sifat terpuji (ash-shifat al-mahmudah), yaitu sifat yang perlu dimiliki setiap muslim. Sifat berani yang disertai dengan perhitungan yang matang mutlak diperlukan dalam menghadapi berbagai permasalahan. Tanpa keberanian, kehidupan tidak akan berjalan efektif. Rasulullah menganjurkan agar umatnya memohon perlindungan kepada Allah dari sifat pengecut. Di dalam Alquran surah arRa'd ayat 11 Allah berfirman, yang terjemahnya : " Sesungguhnya Allah tidak merubah keadaan sesuatu kaum hingga mereka merubah keadaan yang ada pada diri mereka sendiri “. Ayat ini menegaskan bahwa pemecahan masalah kehidupan harus dilakukan dengan kemauan, ikhtiar dan keberanian.

\section{Langkah-langkah Pengambilan Keputusan yang Tepat}

Charles H. Kepner dan Benjamin B. Tregor mengatakan bahwa dalam rangka pengambilan keputusan terdapat empat tahapan yang dominan, yaitu analisis situasi, analisis masalah, analisis keputusan, dan analisis masalah potensial. Dalam analisis situasi, si pengambil keputusan mengidentifikasi, mengklarifikasi, masalah-masalah, menentukan prioritas-prioritas, serta melokalisir masalah. Dalam menganalisis masalah terdapat beberapa langkah yang dapat dilakukan, yaitu :

1. Menentukan tujuan, yaitu menentukan target terlebih dahulu tanpa mencampuradukkan apa yang ingin dicapai dengan apa yang ingin dilakukan

2. Menngumpulkan fakta, yaitu dengan mempelajari catatan-catatan yang relevan, peraturan dan kebiasaan yang berlaku, membicarakan dengan orang yang bersangkutan dan usahakan untuk mengetahui pendapat dan perasaannya

3. Mempertimbangkan fakta dan menentukan tindak lanjut yang harus diambil dengan menghbungkan fakta yang satu dengan yang lain dengan mempelajari pengaruhnya dan menentukan tindakan yang dapat diambil. Hilangkan tindakan yang tidak bijaksana serta tentukan yang paling baik.

4. Mengambil tindakan dengan mempertimbangkan :

a. tentukan siapa yang harus mengambil tindakan secara menyeluruh atau untuk bagian tertentu.

b. Pertimbangkan siapa-siapa yang perlu diberi informasi tentang keputusan atau tindakan yang diambil

27Di dalam Kamus Besar Bahasa Indonesia Berani berarti mempunyai hati yang mantap dan rasa percya diri yang besar dalam menghadapi resiko, kesulitan, dsb. Departemen Pendidikan dan Kebudayaan, Kamus Besar Bahasa Indonesia, op. cit., hal. 121. Menurut Musthafa al-Gulayaini, Keberanian adalah melakukan sesuatu dengan penuh keyakinan atau menunda melakukan sesuatu dengan pertimbangan yang matang. Menurutnya, sifat berani berada di antara dua kutub; pengecut ( $a l-J u b n)$ dan berbuat tanpa perhitungan (at-tahawwur). Musthafa al-Gulayaini, 'Izhzhah an-Nasyi'in, (Birut : al-Maktabah al-Ahliyah, 1949), hal.30

RI'AYAH, Vol. 01, No. 02 Juli-Desember 2016 
c. Tentukan waktu yang tepat untuk melaksanakan tindakan yang telah diputuskan

5. Periksa hasil pelaksanaannya untuk mengetahui apakah tujuan tercapai dan pelajari perubahan-perubahan sikap dan hubungan antara satu pihak dengan pihak lain.

Langkah berikutnya adalah mengklassifikiasikan tujuan berdasarkan prioritas, mempertimbangkan berbagai alternative serta memilih alternatif yang terbaik /optimal untuk dilaksanakan.Pada Pelaksanaan keputusan perlu mengadakan antisipasi terhadap masalah-masalah yang mungkinb timbul dan penyebab timbulnya masalah. 28

James L. Gibson, seperti dikutip H.B siswanto mengemukakan proses pengambilan keputusan sebagai berikut:

a. Penetapan tujuan spesifik serta pengukuran hasilnya

b. Identifikasi permasalahan

c. Pengembangan alternatif

d. Evaluasi alternatif

e. Seleksi alternatif

f. Implementasi keputusan

g. Pengendalian keputusan 29

Lahmuddin Lubis dalam buku Bimbingan Konseling Dalam Persfektif Islam, mejelaskan problem solving dilakukan melalui dua tahap :

1) Tahap wawancara

Pada tahap ini ada enam langkah yang dilakukan seorang konselor kepada klien demi kesuksesan program yang direncanakan, yaitu :

a) Fokuskan perhatian pada klien sewaktu wawancara (memperhhatikan verbal da non verbal)

b) Berikan semangat dan kesempatan kepada klien untuk berbicara dan menjelaskan persoalan yang sedang dihadapinya

c) Tumbuhkan semgat percaya diri pada klien, dan yakinkan bahwa setiap persoalan pasti ada jalan keluarnya

d) Ingat dan catatlah hal-hal penting dari bicara klien

e) Buatlah pengklassifikasian tentang jenis masalah yang dihadapi kelien ( seperti masalah keluarga, social, ekonomi, agama, pendidikan, karir dan sebagainya.

2) Tahap Terapi (rawatan) 
a) Pelajari dengan sungguh latar belakang klien (seperti pendidikan, keadaan nekonomi, lingkungan masyarakat dimana ia lahir dan dibearkan, keadaan orang tua dan agamanya) Dalam hal ini setiap konselor harus menilai dan mengevaluasi (assemen) klien

b) Lakukan pendekatan (communicative approach) dengan berbagai unsur, seperti orang tua, gurunya, dan teman dekatnya

c) Pilihlah waktu yang tepat untuk melaksanakan rawatan, atau terapi

d) Mulailah terapi dalam bentuk sederhana dan terbatas

e) Laksanakan terapi dengan penuh kesungguhan dan ketelitian

f) Analisis dari setiap aspek atau reaksi yang berkembang

g) Adakan tindak lanjut (follow -up) dari setiap terapi yang dilaksanakan ${ }^{30}$

Secara prinsip, layanan konseling seperti dikutip di atas tidak bertengan dengan konsep Islam. Perbedaan hanya terlihat pada prosedur dan teknik penyelesaian masalah terlihat beberapa perbedaan. Demikian juga halnya keformalannya terlihat perbedaan yang sangat jelas, yaitu langkah-langkah dan prosedur konseling versi Barat lebih formal dibanding dengan versi Islam.

Di dalam Islam manusia berpotensi untuk menjadi orang baik (taqwa) dan potensi untuk menjadi orang fasik (fujur) telah ada pada manusia. Oleh karena itu, penekanan dalam proses problem solving versi Islam lebih terfokus pada penyadaran terhadap nilai-nilai agama (transendental), karena menurut ajaran Islam penyebab utama munculnya permasalahan pada manusia adalah disebabkan mausia jauh dari Allah. Untuk itu, jenis yang paling diprioritaskan adalah memberi kesadaran dan motivasi kepada klien agar memperbaiki diri dengan cara bertaubat, mendekatklan diri kepada Allah SWT dan menjauhi larangan-Nya. Dengan kata lain, langkah-langkah yang disarankan kepada klien yang bermasalah adalah sebagai berikut :

1. Mendirikan shalat dengan khusyu'

2. Memperbanyak membaca Alquran

3. Memperbanyak zikir

4. Memperbanyak sedekah 
5. Pemaaf

6. Sabar

7. Ikhlas menerima ketentuan Allah

Penekanan paling utama dari ketujuh langkah ini adalah menganjurkan kelien agar melaksanakan shalat dengan baik, y6aitu memperhatikan syarat zahir dan batin, maka shalat itu mampu mencegah manusia dari perbuatan keji dan munkar.

Keutamaan dan fungsi shalat bagi orang beriman diantara terlihat pada Alquran surah al-Ankabut ayat 45, surah Thaha ayat 14 , surah ar-Ra'd ayat $28 .{ }^{31}$

\section{Upaya Konseling Islami Menumbuhkan Keberanian Manusia}

Menurut Zakiah Daradjat, Kesehatan mental adalah terhindarnya seseorang dari gejala-gejala gangguan jiwa (neurose) dan dari gejala-gejala penyakit jiwa (psychose). Menurut definisi ini, orang yang sehat mentalnya adalah orang yang terhindar dari segala gangguan dan penyakit jiwa. Gangguan jiwa gejalanya seperti cemas yang berlebihan, malas, tidak kegairahan untuk bekerja, rasa badan lesu dan sebagainya ${ }^{32}$. Selain itu, kesehatan jiwa juga ditandai dengan kemampuan memecahkan/menyelesaikan segenap keruwetan batin yang disebabkan oleh berbagai kesulitan hidup. Di samping itu, ia mampu membersihkan jiwanya, dalam arti tidak terganggu oleh berbagai ketegangan, ketakutan dan konflik batin. ${ }^{33}$ Dari keterangan ini, Menurut hemat penulis, keberania (syaja'ah) adalah sifat positif (mahmudah)yang merupakan gejala kesehatan mental yang mesti dimiliki oleh setiap orang. Dengan demikian, sifat ini perlu ditumbuhkan melalui konseling islami ${ }^{34}$. Sebaliknya sifat pengecut atau takut yang berlebihan merupakan gejala gangguan mental (neurose) yang perlu diatasi.

Di dalam bahasa Arab kata konseling disebut al-irsyad atau al-istisyarah, dan kata bimbingan disebut at-taujih. Dengan demikian guidance dan konseling dialih bahasabahasakan menjadi at-taujih wa al-irsyad atau at-taujih wa alistisyarah. Lahmuddin Lubis, ${ }^{35}$ Saiful Akhyar merumuskan pengertian konseling islami ke dalam tiga rumusan pokok;

1. Layanan bantuan kepada klien/konseli untuk mengetahui dan memahami keadaan dirinya sesuai dengan hakekatnya, atau memahami kembali keadaan dirinya. 2

2. layanan bantuan kepada kelien/konseli untuk menerima keadaan dirinya sebagaimana adanya, segi-segi baik dan buruknya, kekuatan dan kelemahannya, sebagai sesuatu yan g yang ditetapkan Allah 3

31Syukur Kholil, op.cit., hal. 33

32 Zakiah Daradjat, Kesehatan Mental, op.cit., hal. 24

33 Saiful, Konseling Islami, op. cit., hal. 74

34 Ibid., hal.73

35Ibid., hlm. 57

RI'AYAH, Vol. 01, No. 02 Juli-Desember 2016 
3. Konseling islami adalah layanan bantuan kepada kelien/konseli untuk memahami keadaan situasi (situasi dan kondisi) yang dihadapi.

Sementa itu, Lahmuddin Lubis merumuskan konseling islami adalah memberikan kesadaran kepada klien agar tetap menjaga eksistensinya sebagai makhluk Allah, dan tujuan yang ingin dicapai bukan hanya untuk kemaslahatan dan kepentingan duniawi semata, tetapi lebih jauh dari pada itu, untuk kepentingan ukhrawi yang lebih kekal dan abadi. ${ }^{36}$

Dari penjelasan di atas dipahami bahwa dalam kegiatan konseling terjadinya kontak antara konselor dan konseli dalam upaya memberikan bantuan kepada konseli untuk memahami eksistensi dirinya.

Menurut Saiful Akhyar, upaya konseling Islami dalam mengatasi masalah kehidupan manusia adalah konseling spiritual. Semua penyakit mental manusia (rasa takut,was-was, kebencian dan lain-lain) akan teratasi dengan konseling spiritual. Sejalan dengan itu, menurut Ramayulis, keimanan merupakan salah satu cara pemeliharaan kesehatan mental karena keimanan mempunyai pengaruh besar pada diri manusia, terutama menubuhkan rasa percaya diri, meningkatkan kemampuannya untuk sabar dan kuat menanggung derita kehidupan, membangkitkan rasa tenang dan tenteram dalam jiwa, menimbulkan kedamaian hati, dan memberi perasaan bahagia. ${ }^{37}$

Dalam hubungan ini, Islam mengajarkan untuk mengembalikan setiap permasalahan hidup manusia kepada Allah yang memberi kehidupan, memberi jalan kemudahan, memberi kekuatan, memberi pertolongan, memberi kesembuhan. Tidak ada kekuatan yang paling besar kecuali kekuatan Allah ${ }^{38}$.

Rasa takut yang pada seseorang merupakan persoalan hidup yang perlu diatasi. Konseling islami berdimensi spiritual 39 merupakan alternatif pemecahan masalah dapat dilakukan. Dalam konseling yang berdimensi spiritual, konseling islami menempatkan Allah pada posisi Konselor Yang Maha Agung, satu-satunya tempat

36Syukur Khalil. op.cit., hlm. 62

37Ramayulis, Psikologi Agama, hlm. 174

38 Saiful Akhyar, Konseling Islami dan Kesehatan Mental, op.cit., hlm. 65

39 Secara garis besar konseling islami memiliki dua dimensi : dimensi spiritual dan dimensi material. Konseling Islam dengan dimensi spiritual adalah memberikan layanan kepada konseli dengan mengarahkannya untuk mendekatkan diri, mengkonsultasikan permasalahannya, serta berserah diri kepada Allah. Konseling islami dengan dimensi material dapat dimaknai sebagai upaya memberikan bantuan kepada konseli tentang permasalahan yang bersumber dari hal-hal yang bersifat material dengan memberikan penyadaran kepadanya akan hakikat jati diri dan tanggung jawabnya sebagai hamba Allah. Ibid hlm. 74. Hal ini dipahami dari terjemahan ayat berikut ini "Ingatlah ketika Tuhanmu berfirman kepada Malaikat: " Sesungguhnya Aku hendak menjadikan seorang khalifah di muka bumi" Alquran dan Terjemahnya, op.cit., hal. 30

RI'AYAH, Vol. 01, No. 02 Juli-Desember 2016 
manusia menyerahkan dan mendekatkan diri serta mengkonsultasikan masalahnya, sebagai sumber memperoleh keberanian dan kekuatan bagi penyelesaian masalah. Dengan demikian, konseling spiritual, konseling islami dapat mengantarkan seseorang pada "self counseling" yaitu ketika seorang klien/konseli yang bermasalah meminta petunjuk Allah bagi penyelesaian masalah tersebut, dengan mengingat dan mendekatkan diri kepada-Nya serta memohon diberikan kekuatan dan ridha-Nya. Konseling dalam konteks ini adalah memberikan dorongan kepada konseli untuk memposisikan dirinya sebagai makhluk Allah yang secara mandiri menyerahkan permasalahan kehidupannya kepada Allah yang diyakini sebagai zat satu-satunya dapat memberi petunjuk penyelesaiannya ${ }^{40}$.

Banyak ayat Alquran yang mengisyaratkan konseling seperti ini, di antaranya seperti terungkap pada terjemahan ayat Alquran berikut ini :

"(tidak demikian) bahkan barang siapa yang menyerahkan diri kepada Allah sedang ia berbuat kebajikan, maka baginya pahala pada sisi Tuhannya dan tidak ada kekhawatiran terhadap mereka dan tidak pula mereka bersedih hati." 41

\section{Kesimpulan}

Berdasarkan Uraian terdahulu dapat disimpulkan bahwa masalah adalah sesuatu yang tidak dapat dipisahkan dari kehidupan manusia. Di dalam Islam, masalah yang dihadapi manusia merupakan ujian dan cobaan dari yang Maha Kuasa. Potensi dasar (fithrah) yang dimiliki manusia menjadi modal penting dalam menyelesaikan masalah hidupnya. Dalam penyelesaian masalah, keberanian mengambil keputusan suatu keniscayaan yang tidak dapat ditinggalkan. Pengambilan keputusan (problem solving) yang efektif harus memperhatikan langkah-langkah dan proses yang tepat. Menumbuhkan keberanian dalam persfektif konseling islami dapat dilakukan konseling berdimensi spiritual sehingga dapat mengantarkan konseli pada self conseling.

\section{Daftar Pustaka}

A.S hornby, et al., Oxford Advanced Learner's Dictionary of Current English. London : Oxford University Press, 1992.

Abdullah Aziz Wahab, Anatomi Organisasi. Bandung: Kerjasama Sekolah Pascasarjana Universitas Pendidikan Indonesia. 2006.

Abu Hamid Muhammad bin Muhammad al-Gazali, Ihya' Ulum ad-Din, Juz, I, (Kairo : Maktabah wa Maktabah al-Masyhad al-Husain, tt. Abuddin Nata, Kapita Selekta Pendidikan Islam. Bandung : Angkasa, 2003.

40Saiful Akhyar, Konseling Islami dan Kesehatan Mental, op. cit., hal. 77

RI'AYAH, Vol. 01, No. 02 Juli-Desember 2016 
Abuddin Nata, Pendidikan dalam Persfektif Alquran. Jakarta : UIN Jakarta Press, 2005.

Departemen Agama RI, Alquran dan Terjemahnya. Madinah Munawwaroh, Mujamma' Khadim al Haramain asy-Syarifain, $1412 \mathrm{H}$.

Departemen Pendidikan dan Kebudayaan, Kamus Besar Bahasa Indonesia. Jakarta : 1995.

H.B. Siswanto, Pengantar Manajemen. Jakarta : Bumi Aksara, 2010.

Hasan Langgulung, Manusia dan Pendidikan. Jakarta : Pustaka al-husna baru, 2004.

Muhaimin dan Abd.Mujib, Pemikiran Pendidikan Islam. Bandung : Trigenda Karya, 1993,

Musthafa al-Gulayaini, 'Izhzhah an-Nasyi'in. Birut : al-Maktabah al-Ahliyah, 1949.

Prayitno dan Erman Amti, Dasar-Dasar Bimbingan dan Konseling. Jakarta : Rineka Cipta, 2008.

Ramayulis. Psikologi Agama, (Jakarta : Kalam mulia, 2009), hlm. 38-51)

Saiful Akhyar, Konseling Islami dan Kesehatan mental, (Bandung : Citapustaka, 2011), hlm.167

Syukur Kholil (Ed.), Bimbingan Konseling Dalam Persfektif Islam. Bandung : Cita Pustaka, 2009.

Zakiah Daradjat, Kebahagiaan. Jakarta : YPI Ruhama', 1998.

Zakiah Daradjat, Kesehatan Mental. Jakarta : CV Masagung, 1989 